\title{
Labour
}

Journal of Canadian Labour Studies

Le Travail

Revue d'Études Ouvrières Canadiennes

\section{Emily L. Thuma, All Our Trials: Prisons, Policing, and the Feminist Fight to End Violence}

\section{Joshua David Michael Shaw}

Volume 85, printemps 2020

URI : https://id.erudit.org/iderudit/1070924ar

DOI : https://doi.org/10.1353/1lt.2020.0023

Aller au sommaire du numéro

Éditeur(s)

Canadian Committee on Labour History

ISSN

0700-3862 (imprimé)

1911-4842 (numérique)

Découvrir la revue

Citer ce compte rendu

Shaw, J. (2020). Compte rendu de [Emily L. Thuma, All Our Trials: Prisons, Policing, and the Feminist Fight to End Violence]. Labour / Le Travail, 85,

318-320. https://doi.org/10.1353/llt.2020.0023 d'utilisation que vous pouvez consulter en ligne. 
freestanding slave quarters in the North, located north of Boston in Medford - is important because New England loves relishing in its history; yet, the history of slavery and colonization is as widely discussed, or takes up the physical landscape as much as the American Revolution. From the origins of settler colonialism and Indigenous slavery in the Massachusetts Bay Colony, to the founding of Brown University, to Mum Bett and Quok Walker's landmark Massachusetts Supreme Court cases, Hardesty shows how Black and Indigenous New Englanders at every turn of its history, fought against their subjection. In doing so, despite their subjected statuses, they still created lives for themselves. Black Lives, Native Land, White Worlds is a phenomenal way to begin learning more about them.

AdAM MCNEIL

Rutgers University

\section{Emily L. Thuma, All Our Trials: Prisons, Policing, and the Feminist Fight to End Violence (Champagne: University of Illinois Press 2019)}

THE IMAGE OF PRISONS as judicious machines of enclosure, and the conception of impartial justice this image serves, are shattered by the activism documented in Emily L. Thuma's All Our Trials: Prisons, Policing, and the Feminist Fight to End Violence. Looking at archives in the United States, Thuma follows the trajectories of feminist movements in the 1970s and the 1980s, whose fringes fostered an abolitionist and anti-carceral mode of feminism. These movements were abolitionist and anti-carceral in that these women sought the dissolution of and alternatives to prisons. For example, rallying behind women prosecuted and incarcerated for killing their assaulters
- cases in which self-defence was argued - these women attended to the failure of the state to protect women from sexual violence. In doing so, the "liberal legal imaginary" (80) in which victims are clearly differentiated from criminals was upended. But these fringes also went further, in that they also advocated for compassionate and communal interventions for those who raped or committed sexual assault, instead of participating in the violence of the state. The state was identified as the ultimate assaulter - particularly a state engaged in advancing a white, male, and capital-controlling class - and abetting that class violence by seeking justice through the state's criminal legal system guaranteed the problem in perpetuity.

Critically, Thuma tells us, this cry for abolition was informed by looking inward and to others as women, particularly as Black, Indigenous, Latina, and/or incarcerated women, and drawing from their lived experience. By experiencing the prison and policing as inseparable from projects of white supremacy and the alienation and exploitation of labourers, these women diagnosed incarceration as a political practice continuous with colonial and capitalist social formations. Criminality was not the disease of the body, to be extracted through enclosure; instead, these women saw beyond this simulacrum and dislocated carceral frames to bring into focus the manifold violence of the state. Incarceration was constitutive of the criminal and the inmate, alongside social formations that impoverished, marginalized, and harmed people of colour, Indigenous peoples, immigrants, queer and trans peoples, and workers. All prisoners were in fact political prisoners to these women, in that their race, gender, and bodies transgressed preferred political arrangements and institutions thought of as conducive 
to the extraction, security, and movement of capital.

Thuma's rich account documents how these abolitionist, anti-carceral movements emerged from women's "bodily confrontations with institutional and interpersonal violence," (3) which allowed extensions of solidarity to form, albeit never permanently, an affective body of resistance. This affective body stretched across prison walls through correspondence, newsletters, and other written media, which allowed connections to form in the resulting "coalitional space" (9) inside, between, and outside prisons. These textually mediated connections both produced and archived subaltern understandings about state violence, through which many women could contribute and relate. Importantly, this coalitional space was decentralized, relying upon formal and informal arrangements, allowing for a multiplicity of claims and stories to proliferate, enabling many to look inward at their position and experience, and feel affected by the enactment of state violence. Strikes inside prisons, protests, letterwriting campaigns, newsletters, conferences, and witnessing criminal trials in the public galleries, were all modes of direct action effected from and coordinated within this space, expanding the affective body to include more of the public in their movement of resistance.

By documenting these coalitional spaces, Thuma shows how the prison is actually porous, undercutting the image of prisons as total institutions of enclosure. The enclosure of a prisoner is incomplete, allowing for the exchange, production, and archiving of ideas, strategies and, importantly, affective connection across prison walls. Indeed, Thuma shows that systems of constraint and enclosure advanced by the medicalization, policing, and incarceration of political movements increase the women placed in and otherwise affected by prison, expanding potential bodies for these collectives to recruit. In and through this discrepant space between image and actuality, incarcerated and non-incarcerated women encountered one another, imagining an alternative to the state, its violence, and carceral institutions.

Coalitional space was fleeting. Thuma shows how those involved understood that the community they sought to form was "the result of an intentional and possibly arduous process of social organisation," (81) and that their reliance on volunteer labour, from disparate groups of varying formality and means, always rendered its constitutive coalitions fragile. Thuma notes that these coalitions endured for as long as they did through recognising and attempting to overcome structural difference between women. For example, salaried positions were created for Black organizers, predominantly white middle-class groups provided logistical and financial support to Black, Latina, and Indigenous women who assumed leadership positions, and the writings and analyses of prisoners were prioritised and circulated widely. Relatedly, I was struck by the example of organizers navigating marginal members' trans-exclusionist agitations, the latter of whom claimed that trans women did not belong in their women-only spaces. These organizers responded with a trans-inclusionist approach, noting their shared commitment to end carceral violence often directed to policing and punishing gender non-conformance and other forms of resistance to capitalist and racist oppressions. Solidarity reached past difference, lessons which may be invaluable to organizers today.

While fragile, the intense and broad mobilisations in these coalitional spaces produced a deep and sophisticated account of the state, punishment, and the 
imperative for abolition, in contrast to mainstreamed feminists. The legacy of this labour continues to find expression in ongoing intellectual and activist work toward abolition and critiques of carceral institutions. Thuma participates in that important labour by attending to and reconstructing their subaltern understandings, strategies, and affects. If we are open to it, Thuma's account may, like the letters and newsletters she studied, (re-)produce the coalitional space across temporal as well as spatial dimensions, potentially including more of us than before in that affective body of resistance.

Thuma conceptualizes coalitional space as a counterpublic sphere, contrasted to a public sphere dominated by law-and-order or tough-on-crime hegemony and ever-expanding carceral institutions. Thuma also places this counterpublic sphere on the periphery of mainstreamed feminist movements, the latter of whom recede from view in her account, although she frames the coalitional space as a site in which boundaries of feminism are contested. Possible perturbations to the coalitional space seem to be resolved, albeit tenuously, through negotiation and consensus. This move appears deliberate to me. Thuma states in the introduction that she is focussing on spaces heretofore ignored as contributing to abolitionist and anti-carceral moves against state violence. It is understandable then that the distinctiveness of the counterpublic would be attended to over any other considerations. But going forward, in the coalitional space Thuma reopened, I think it could be helpful to interrogate the continuities, as well as disjunctions, between counterpublic and public spheres, to trouble the boundary between them and to see how it is possible for both to affect, and entangle with, each other. Such a move might require conceptualizing coalitional space as more than discursive, by accepting that it is constituted by matter other than text and that mediating structures can work in multiple directions.

Joshua David Michael Shaw

York University

\section{Anthony Carew, American Labour's Cold War Abroad: From Deep Freeze to Détente, 1945-1970 (Edmonton: Athabasca University Press 2018)}

\section{In AMERICAN LABOUR'S Cold War} Abroad, Anthony Carew reconstructs "the admittedly obscure world of international trade union politics, with its complex institutional structure." (6) Carew, an Honorary Visiting Reader in International Labour Studies at the University of Manchester, has been researching and publishing on this subject for decades, and the book reflects his considerable expertise. American Labour's Cold War Abroad principally focuses on the AFL-CIO (American Federation of Labour-Congress of Industrial Organizations) and, in particular, on the activities of five men: Irving Brown, Jay Lovestone, George Meany, and Walter and Victor Reuther. The depth of analysis on these major figures in U.S. labour history, spread over 25 years, is the strength of this book. Yet further exploration of broader contextual and historiographical questions would do more to engage non-specialists.

These five men became powerful figures in international trade union circles because, as Carew documents extensively, they controlled and handed out a steady supply of money. Lovestone controlled the AFL's Free Trade Union Committee, Brown was Lovestone's protégé and the primary contact with dozens of overseas unions, and Meany was the longtime AFL/AFL-CIO president. All three were committed anti-communists who advocated the principle of "free" 